\title{
Manajemen kepala Madrasah Ibtidaiyah dalam menumbuhkan pendidikan karakter religius pada era digital
}

\author{
Murni Yanto ${ }^{\left.1^{*}\right)}$ \\ ${ }^{1}$ Institut Agama Islam Negeri (IAIN) Curup, Indonesia
}

\section{Article Info}

Article history:

Received Aug 11th, 2020

Revised Sep 19th, 2020

Accepted Nov 27th, 2020

\section{Keyword:}

Manajemen

Pendidikan karakter anak

Madarasah Ibtidaiyah

Religius

Era digital

\begin{abstract}
This study aims to determine how the management of madrasah principals in fostering religious character education in the digital era. This study uses a qualitative method. The principal of State Islamic Elementary School 1 in Dusun Curup, Rejang Lebong Regency is the main sample in this study, the data collection technique uses the interview method, observation and documentation, the data analysis of the research results uses the reduction technique, triangulation and the conclusion of the research data. Based on this research, it is concluded that the management of the head of State Islamic Elementary School in fostering religious character education in the digital era by leading to the psychological side of students which has implications for behavior, character building in children is carried out in order to create students who have good knowledge and behavior. The character of State Islamic Elementary School students has values that come from Pancasila, religion, culture, and national education goals, namely honest, tolerance, religious, discipline, cooperation, creative, democracy, independence, national spirit, curiosity, love for the country, friendly, communicative, respect for achievement, love peace, care for the environment, love to read, care about socially, and have responsibility. Students' religiosity is shown by obedient attitude or behavior in carrying out the religious teachings that have been adhered to, being tolerant of the implementation of religious worship and living in harmony with followers of other religions. The results showed that the management of the head of State Islamic Elementary School in fostering religious character education had gone well by planning, organizing, implementing and evaluating it very well. Information technology helps facilitate all human activities, information retrieval, convey information and literacy about the addition of knowledge in learning by utilizing technology, so that students can learn by making maximum use of learning resources.
\end{abstract}

\section{Corresponding Author:}

Murni Yanto,

Institut Agama Islam Negeri (IAIN) Curup

Email: yanto.murni65@gmail.com

\section{Pendahuluan}

Manajemen berasal dari bahasa Inggris management yang berarti tata laksana, tata pimpinan dan tata pengelola.Artinya manajemen adalah sebagai suatu proses yang diterapkan oleh individu atau kelompok dalam upaya upaya koordinasi untuk mencapai tujuan (Awaludin Pimay, 2013). Manajemen merupakan serangkaian kegiatan yang didesain untuk mencapai tujuan organisasi dengan menggunakan sumber daya secara efisien dan efektif dilakukan dalam lingkungan yang senantiasa berubah dari waktu ke waktu (Yanto, 2019).

Kepala madrasah sebagai pemimpin dilembaganya,maka dia harus mampu membawa lembaganya kearah tercapainya tujuan yang telah ditetapkan,dia harus mampu melihat adanya perubahan serta 
mampu melihat masa depan dalam kehidupan gelobalisasi yang lebih baik. Kepala sekolah (madrasah) harus bertanggung jawab atas kelancaran dan keberhasilan suatu urusan pengaturan dan pengelolahan secara formal kepada atasannya atau informal kepada masyarakat yang telah menitipkan anak didiknya (yanto, 2020). Kepala madrasah harus mampu melahirkan gagasan yang inovatif yang berguna untuk menghasilkan alternatif kebijakan dalam membangun (Yanto, M., \& Fathurrochman, 2019).

Berbicara tentang karakter merupakan hal yang sangat penting dan mendasar. Karakter adalah Prilaku atau akhlak seseorang yang membedakan manusia dengan binatang. Manusia tanpa karakter adalah manusia yang sudah "membinatang". Orang-orang yang berkarakter kuat dan baik secara individual maupun sosial ialah mereka yang memiliki akhlak, moral, dan budi pekerti yang baik. Mengingat begitu urgennya karakter, maka institusi pendidikan memiliki tanggung jawab untuk menanamkannya melalui proses pembelajaran (Zubaedi, 2011). Dalam dunia pendidikan sering kita hampiri persoalan-persoalan yang selalu mengitarinya, terutama pada unsur anak.

Pendidikan memegang peranan penting bagi suatu bangsa,sebab melalui proses pendidikan akan melahirkan manusia yang berkualitas yang akan menentukan kualitas bangsa (Yanto., 2017). Entah sadar atau tidak hal itu pasti terjadi pada setiap proses pembelajaran berlangsung. Apalagi pada jenjang pendidikan dasar atau sekolah dasar. Kita ambil contoh yang sering kita amati bahkan yang pernah terjadi pada diri kita seperti, anak sering kali mengganggu teman, mondar-mandir di dalam ruangan, membuat gaduh di dalam kelas dan lain sebagainya (Jihad, Salimul, 2018).

Memiliki anak yang berakhlak mulia, moral yang baik adalah dambaan orang tua pada umumnya. Akan tetapi harapan tersebut harus diimbangi dengan upaya yang tepat dan sungguh-sungguh, terkadang pendidik baik orang tua maupun guru melakukan kesalahan dalam mendidik anak sehingga pembentukan karakternya tidak sesuai dengan harapan (Ridwan Abdullah Sani dan M.Kadri, 2016). Untuk itu Perlunya anak diberikan pendidikan karakter dalam keluarga disebabkan karena masyarakat Indonesia sudah luntur akan budaya leluhurnya, sebagai contoh: sudah tidak ada lagi sikap hormat antara anak dengan orang tua, gurunya, ataupun tidak adanya tenggang rasa antar sesama (Saputra, 2019)

Kualitas pendidikan karakter setidaknya dapat diukur dari beberapa faktor. Salah satu diantaranya adalah faktor guru, lingkungan dan lain sebagainya. Tugas guru tidak hanya sebatas sebagai penyampai materi pelajaran dikelas. Guru dalam artian mempunyai tugas yang lebih kompleks bagi anak didiknya. Dengan kata lain, di pundaknyalah tugas pendidikan dan pengajaran kepada anak diemban (Amirulloh Syarbini, 2015).

Mendidik tidak hanya sekedar mengajar, Mendidik tidak semata-mata mentransfer pengetahuan kepada generasi muda. Lebih dari itu, mendidik adalah menanamkan nilai-nilai, sikap dan perilaku. Dalam konteks ini, dimensi utama pendidikan adalah moral, yakni tindakan membimbing peserta didik untuk mengikatkan diri secara sukarela kepada nilai-nilai luhur (akhlaqul karimah). Maka dalam pendidikan moral yang harus diusahakan ialah agar kesenjangan ini melebar berarti membiarkan tumbuhnhya kemunafikan (Aris Shoimin, 2014).

\section{Metode}

Penelitian ini menggunakan metode kualitatif. Sampel utama dalam penelitian ini adalah Kepala Madrasah Ibtidaiyah Negeri 1 Dusun Curup Kabupaten Rejang Lebong, teknik pengumpulan data menggunakan metode wawancara, observasi dan dokumentasi. Data hasil penelitian kemudian penulis analisis menggunakan teknik reduksi, triangulasi dan penarikan kesimpulan data hasil penelitian (Miles and Hubberman, 2015); (Ristianti, et.al, 2019). Data yang dianalisis dalam penelitian kaulitatif adalah kata-kata dan perbuatan manusia, sehingga bukan deskripsi angka, melainkan definisi dan penjelasan secara kualitatif (Afrizal, 2015). Penelitian ini merupakan hal yang dilakukan dengan pendekatan ilmu sosial, dimana penelitian digunakan secara orisinil, peneliti menjadi pelaku utama dalam penelitian sehingga data yang diperoleh menjadi valid dan dapat dipercaya kebenarannya (Yanto, M., \& Fathurrochman, 2019). 


\section{Hasil dan Pembahasan}

\section{Pengertian Manajemen}

Manajemen organisasi manusia dalam organisasi tidak terlepas dari sistem yang telah dibuat di organisasi tersebut. Sistem itu dibuat berdasarkan kesepakatan anggotanya (Fathurrochman, 2020). Manajer organisasi adalah yang paling berperan dalam pembentukan sistem tersebut, oleh karena itu seorang manajer diharapkan orang yang berwawasan luas dan mampu mengelola organisasi (Yanto, 2020). Manajemen adalah serangkaian kegiatan yang didesain untuk mencapai tujuan organisasi dengan menggunakan sumber daya secara efisien dan efektif dan dilakukan dalam lingkungan yang senantiasa berubah dari waktu ke waktu. Efektif berarti tercapai tujuan yang ditetapkan dan efisien berarti mencapai tujuan dengan menggunakan sedikit mungkin sumber daya yang tersedia. Menurut Piaget dalam Mgs. Nazarudin ( 2007:163).

Manajemen merupakan serangkaian kegiatan yang didesain untuk mencapai tujuan organisasi dengan menggunakan sumber daya secara efisien dan efektif dan dilakukan dalam lingkungan yang senantiasa berubah dari waktu kewaktu. Efektif berarti tercapai tujuan yang ditetapkan dan efisien berarti mencapai tujuan dengan menggunakan sedikit mungkin sumber daya yang tersedia (Yanto, 2018).

Suatu lembaga pendidikan akan dapat berfungsi dengan memadai kalau memiliki sistem manajemen yang didukung dengan sumber daya manusia (SDM), dana dan sarana-prasarana (Kusen, et.al, 2018). Manajemen sekolah akan efektif dan efisien apabila didukung oleh sumber daya manusia yang profesional untuk mengoperasikan sekolah, kurikulum yang sesuai dengn tingkat perkembangan dan karateristik siswa., tenaga kependidikan yang handal dan semuanya itu didukung oleh sarana-prasarana yang memadai untuk mendukung kegiatan belajar mengajar.

Secara etimologi, kata Manajemen berasal dari bahasa Prancis kuno Menagement yang memiliki arti seni melaksanakan dan mengatur. Dalam bahasa inggris, kata manajemen berasal dari kata to manage artinya mengelola, membimbing, dan mengawasi (Fathurrochman, 2020). Dengan memperhatikan pengertian manajemen diatas, manajemen dapat di definisikan sebagai kegiatan mengelola berbagai sumber data dengan cara bekerja sama dengan orang lain melalui proses tententu untuk mencapai tujuan organisasi secara efektif dan efisien (Arifin M. Dan Barnawi, 2012).

Manajemen pendidikan dapat di definisikan sebagai seni dan ilmu mengelola sumber daya pendidikan untuk mewujudkan suasana belajar dan proses pembelajaran agar peserta didik secara aktif mengembangkan potensi dirinya dalam rangka memiliki kekuatan spriritual keagamaan, pengendalian diri, kepribadian, kecerdasan, akhlak mulia, serta keterampilan yang dirperlukan dirinya, masyarakat, bangsa dan negara. Manajemen pendidikan dapat pula didefinisikan sebagai seni dan ilmu mengelola sumber daya pendidikan untuk mencapai tujuan pendidikan secara efektif dan efisien. Sumber daya pendidikan adalah sesuatu yang dipergunakan dalam penyelenggaraan pendidikan, baik dalam bentuk sumber daya manusia, sumber daya finansial, maupun sumber daya material, termasuk di dalamnya adalah teknologi informasi dan teknologinya (Hartani A.L, 2011). Pendidikan pada saat ini merupakan harapan setiap lembaga yang berorientasi pada mutu,hal ini mendorong semua pihak terutama lembaga pendidikan untuk berlomba-lomba menjadi institusi sebagai pusat unggulan (Yanto.M, 2017).

\section{Fungsi manajemen}

Fungsi manajemen diantaranya adalah perencanaan, proses memikirkan dan menetapkan kegiatankegiatan atau program-program yang akan dilakukan pada masa yang akan datang untuk mencapai tujuan tertentu (Sagala, 2011). Fungsi perencanaan antara lain menentukan tujuan atau kerangka tidakan yang diperlukan untuk mencapai tujuan tertentu. Perencanaan dilakukan dengan mengkaji kekuatan dan kelemahan organisasi, menentukan kesempatan dan ancaman serta menentukan strategi, kebijakan dan program (Rohiat, 2010).

Organisasi merupakan proses pembagian kerja kedalam tugas-tugas yang lebih kecil, membebankan tugas-tugas itu kepada orang yang lebih sesuai dengan kemampuannya, mengalokasikan sumberdaya, dan mengkoordinasikannya dengan aktivitas pencapaian tujuan organisasi (Ula, 2013); 3).

Pengarahan dorongan yang akan memberikan motivasi dalam suatu organisasi. Pengawasan erat kaitannya dengan perencanaan karena melalui pengawasan efektivitas manajemen dapat diukur. Jadi merencanakan program kegiatan bersama warga masyarakat berdasarkan panduan yang dalam kegiatan organisasi hasil rapat seluruh anggota terdiri dari kegiatan mingguan dan kegiatan pertengahan bulan. 


\section{Karakter Religius Anak}

Karakter bukanlah bawaan seseorang sejak lahir. Karakter ada dan terbentuk melalui proses belajar dari keluarga, lingkungan, dan anggota keluarga. Karakter merupakan kualitas dari seseorang yang pada akhirnya akan membedakan dirinya dengan orang lain. Karakter bisa dikatakan berhubungan dengan kepribadian, dan perilaku tetapi keduanya merupakan hal yang berbeda. Kepribadian merupakan bentuk cara atau etika kita menunjukkan sikap saat berhadapan dengan orang lain, seperti cara berjalan, berpakaian, menyampaikan pendapat dan lain-lain (Mia Zakaria dan Dewi Arumsari, 2018).

Teori Karakter Corley dan Philip menyatakan karakter merupakan sikap dan kebiasaan seseorang yang memungkinkan dan mempermudah tindakan moral. Karakter di maknai sebagai cara berpikir dan berprilaku yang khas tiap individu untuk hidup dan bekerja sama, baik dalam lingkup keluarga, masyarakat, bangsa, dan negara. Individu yang berkarakter baik adalah individu yang dapat membuat keputusan dan siap mempertanggungjawabkan setiap akibat dari keputusannya (Rahmadanni, 2017).

Aristoteles melihat karakter sebagai kemampuan melakukan tindakan yang baik dan bermoral. Psikolog Frank Pittman mengamati bahwa kestabilan hidup kita bergantung pada karakter. Membangun karakter diakui jauh lebih sulit dan membutuhkan waktu yang lama. Coon mendefinisikan karakter sebagai suatu penilain subjektif terhadap kepribadian seseorang yang berkaitan dengan atribut kepribadian yang dapat atau tidak dapat diterima oleh masyarakat (Zubaedi, 2011). Karakter juga biasanya diistilahkan dengan kata moral. Dalam pengertian Soloman, mengatakan bahwa moral menekankan pada karakter. Karakter juga biasanya diistilahkan dengan kata moral. Dalam pengertian Soloman, mengatakan bahwa moral menekankan pada karakter individu Yang bersifat khusus, bukan pada aturan-aturan dan ketaatan. Nilai moral atau moralitas adalah nilai yang mengatur kehidupan manusia, baik sebagai pribadi yang bermanfaat maupun dalam rangka mengatur keharmonisan dalam hidup bermasyarakat (Habsari, 2017).

Beberapa pendapat diatas dapat disimpulkan bahwa karakter adalah sikap atau kebiasaan seseorang untuk melakukan sebuah tindakan yang baik dan bermoral. Karakter juga menunjukan jati diri seseorang, siapa anda sesungguhnya, karakter juga bisa di katakan tabiat, budi pekerti, dan akhlak seseorang yang tidak bisa disamakan dengan yang lain karena karakter seseorang biasa terbentuk dari keluarga, lingkungan dan guru yang memberikan pemahaman kepada seorang anak karena karakter bukan sikap dari lahir.

Dalam UU Nomor 23 Tahun 2002 Tentang Perlindungan Anak dikatakan bahwa anak merupakan amanah dan karunia Tuhan Yang Maha Esa, yang mana dalam dirinya melekat harkat dan martabat sebagai manusia seutuhnya, anak adalah tunas, potensi dan generasi muda penerus cita-cita perjuangan bangsa, memiliki peran strategis dan mempunyai ciri dan khusus yang menjamin kelangsungan eksistensi bangsa dan Negara pada masa depan. Anak ialah seseorang yang belum berusia 18 tahun, termasuk anak yang masih dalam kandungan ( Pasal 1 ayat (1) (P. Febrianti, 2014).

Karakter anak sekolah dasar berlangsung sekitaran usia 6-12 tahun. Masa itu sering disebut juga masa sekolah, yaitu masa matang untuk belajar atau sekolah. Pada masa itu anak-anak lebih mudah diarahkan, diberi tugas yang harus diselesaikan, dan cenderung mudah untuk belajar berbagai kebiasaan seperti makan, tidur, bangun, dan belajar pada waktu dan tempatnya dibandingkan dengan masa pra sekolah. Dilihat dari karakteristik anak pertumbuhan fisik dan psikologisnya anak mengalami pertumbuhan jasmaniah maupun kejiwaannya. Pertumbuhan dan perkembangan fisik anak berlangsung secara teratur dan terus menerus kearah kemajuan. Anak SD merupakan anak dengan kategori banyak mengalami perubahan yang sangat drastis baik mental maupun fisik (Kurniawan, 2015).

\section{Masa Anak-anak dan Anak Sekolah (6-12 Tahun)}

Dengan Belajar keterampilan fisik untuk pertandingan biasanya sehari-hari;b)Membentuk sikap yang sehat terhadap dirinya sebagai organisme yang sedang tumbuh berkembang;c)Belajar bergaul dengan teman-teman sebayanya;d)Belajar peranan social yang sesuai sebagai pria atu wanita;e)Mengembangkan keterampilan dasar dalam membaca, menulis, serta berhitung;f)Mengembangkaan kata hati, moralitas, dan suatu skala nilai-nilai;g) Mecapai kebebasan pribadi;g)Mengembangkan sikap-sikap terhadap kelompok dan institusi sosial (Azam, 2016).

Anak-anak anak akan membentuk prilakunya dari mencontoh atau meniru apa yang dilihatnya sehari-hari,hal ini maka orang-orang yang berada di sekitar anak akan menjadi model (Yanto.M, 2017). Dapat disimpulkan bahwa anak adalah amanah dan karunia yang Allah berikan kepada orangtua dalam keadaan suci, anak sekolah itu berkisaran umur 6-12 tahun dimana masa itulah masa matang bagi anakanak untuk diarahkan menjadi lebih baik. 
Kata dasar Religius ialah religi yang berasal dari bahasa asing religius biasanya bentuk dari kata benda yang berarti agama atau kepercayaan, kepercayaan ini akan muncul adanya sesuatu kekuatan kodrat di atas manusia. Sedangkan religius berasal dari religius yang mana bersifat religi yang mana melekat pada setiap diri seseorang. Religius adalah salah satu nilai karakter sebagai perilaku dan sikap yang patuh dan taat dalam melaksanakan ajaran agama yang dianut masing-masing manusia, toleran terhadap pelaksanaan ibadah agama lain, dan hidup rukun, damai dengan sesama pemeluk agama yang berbeda (Y. Febrianti, 2019).

Karakter religius sangat dibutuhkan oleh setiap generasi muda ataupun tua, tapi lebih diutamakan bagi generasi muda dalam menghadapi perubahan jaman dan degradasi moral. Dalam hal ini generasi muda diharapkan agar generasi muda memiliki perilaku yang baik yang didasarkan dengan ketentuan dan ketetapan agama yang telah di tentukan (Y. Febrianti, 2019).

Dari pejelasan diatas dapat dipahami bahwa Karakter Religius Anak merupakan karakter yang melekat pada diri anak dalam hal sikap, prilaku, serta tindakan yang selalu taat dan patuh pada ajaran agama yang ada. Karakter Religius anak harus selalu sesuai dengan ajaran agama yang telah dianut baik dari segi akhlak, adab, sikap, tindakan serta prilaku seorang anak agar anak bisa memliki karakter yang baik, karakter yang diinginkan oleh semua orangtua dan guru.

Beberapa tindakan yang menunjukkan seseorang yang berkarakter religius yaitu; 1)Orang yang berkarakter religius bisa dilihat dari perilaku seseorang yang akan menunjukkan kepatuhan dalam beribadah seperti sholat, berakhlak yang baik, dan sebagainya serta keteguhannya dalam keyakinan;2) Sebaiknya sesame manusia dan alam sekitar harus selalu menjaga hubungan yang baik;3) Apabila seseorang berkata sopan dan dengan perkataan yang baik dan juga mengucapkan salam saat bertemu dan berpisah dengan sesame, karena mengucapkan salam adalah kewajiban bagi setiap uamt muslim;4) Orang yang memiliki karakter religius seharusnya harus selalu berpakaian yang syar'i menutupi aurat sesuai dengan ajaran islam;5) Seseorang yang mempunyai karakter religius biasanya bisa dilihat dari cara seseorang taat dan patuh terhadap ibu-bapaknya, keluarga dan tetangga terdekatnya (Y. Febrianti, 2019). Dapat dipahami bahwa seseorang yang memiliki karakter religius adalah anak yang memilik akhlak yang baik, bertutur kata yang sopan, dan menunjukkan bagaimana kepatuhannya kepada ajaran agama baik dalam beribadah, seperti sholat, bagaimana cara mengucapkan salam saat bertemu, berpenampilan yang baik, berbuat baik kepada orangtua. Orang yang memiliki karakter religius senantiasa menjaga tingkah laku dan sikapnya baik terhadap Guru, orang tua, keluarga, dan Masyarakat.

\section{Nilai-Nilai Karakter}

Karakter memiliki 18 nilai yang bersumber pada Pancasila, Agama, Budaya, serta tujuan pendidikan nasional, yakni: 1) Jujur, 2) tranpleransi, 3) Religius, 4) Displin, 5) Kerja Sama, 6) Kreatif, 7) Demokrasi, 8) Mandiri, 9) Semangat kebangsaan, 10) Rasa Ingin Tahu, 11) Cinta Tanah Air, 12) Bersahabat Komunikatif, 13) Menghargai Prestasi, 14) Cinta Damai, 15) Peduli Lingkungan, 16) Gemar Membaca, 17) Peduli Sosial, dan 18) Tanggung Jawab (Sani, 2017). Nilai-nilai ;a)Religius ialah suatu sikap atau tingkah laku yang patuh dalam melaksanakan ajaran agama yang telah dianut, toleran terhadap pelaksanaan ibadah agama serta hidup rukun dengan pemeluk agama lain;b) Toleransi bagi setiap bangsa Indonesia toleransi sangatlah diperlukan mengingat kemajemukan hidup didalam keberagaman, suku bangsa, golongan serta etnik.

Toleransi juga memliki suatu pengertian sifat atau sikap, batas ukur untuk penambahan atau pengurangan yang masih diperbolehkan, dan penyimpangan yang masih dapat diterima dalam suatu pengukuran kerja, sikap yang menghargai perbedaan yang ada;c)Disiplin guru banyak yang merasakan kewalahan menghadapi anak didik yang sulit diatur, yang cendrung membantah saat dinasihati, serta sering kali melanggar aturan. Dalam menghadapi keadaan seperti ini, tidak heran jika guru menggunakan suatu jalan untuk menanamkan suatu sikap disiplin pada para anak didiknya;d)Jujur Menanamkan kejujuran pada anak didik sejak dini tentu saja dapat dilakukan saat mereka masih duduk dibangku Sekolah Dasar;e) Kerja keras adalah perilaku yang menunjukkan bagaimana upaya seseorang dalam bersungguh-sungguh dalam mengatasi berbagai masalah.

\section{Peran pendidikan dalam penanaman karakter}

Penanaman karakter pada perannya bidang pendidikan: a) Pembinaan watak, ( jujur, cerdas, peduli, tangguh) merupaka tugas utama pendidikan; b)Mengubah sikap buruk tahap demi tahap yang akhirnya menjadi baik;c) Karakter merupakan sikap yang tertanam di dalam jiwa dan dengan sifat itu seseorang secara spontan dapat dengan mudah memancarkan sikap,tindakan dan perbuatan;d) Karakter adalah 
sifat yang terwujud dalam kemampuan daya dorong dari dalam keluar untuk menampilkan perilaku terpuji dan mengandung kebijakan (Daryannto, 2013).

Penanaman nilai karakter dapat diimplementasikan dan dijadikan budaya sekolah,proses efektif untuk membangun budaya sekolah dengan melibatkan dan mengajak semua pihak atau pemangku kepentingan untuk bersama-sama memberikan komitmennya.

\section{Pendidikan karakter di era digital}

Masalah yang harus dilakukan oleh orang tua terhadap anak dalam pengasuhan di Era Digital; a) Meningkatkan dan memperbaharui wawasan tentang internet dan gagjet.Orang tua tidak bisa mengawasi anak-anak apabila orang tua gagap teknologi; b) Jika dirumah ada internet, posisikan diruang keluarga dan siapa yang dapat melihat apa yang dilakukan dalam mengakses internet; c) Membatasi waktu pada anak dalam menggunakan gadget dan internet; d) Memberikan pemahaman dan kesadaran bersama akan dampak negatif dari internet atau gadget; e) Secara tegas melarang sesegera mungkin jika tidak ada yang tidak pantas ditonton; f)Menjalin komunikasi yang terbuka dua arah dengan anak-anak (Yulia Palupi, 2015).

Anak-anak sekarang banyak beritegrasi dengan teknologi,seperti gadget dan video games, sekarang anak-anak banyak menghabiskan waktu dengan media dan mengahabiskan 2 jam di hari sekolah dan 6 jam pada hari libur,waktu bermain internet rata-rata 2 jam (Salman Hasibuan, 2015).

Anak-anak di era digital sudah dimanjakan dengan teknologi yang serba canggih seperti bahan pelajaran mealui situs Geogle,permainan tradisional sudah ditinggalkan. Ciri-ciri generasi digital; 1) Generasi digital ramai-ramai membuat akun di media social untuk membuktikan kepada dunia bahwa mereka ada; 2) Generasi digital cendrung lebih terbuka,blak-blakan,dan berfikir lebih agresif; 3) Generasi digital cendrung ingin memperoleh kebebasan.Mereka tidak suka diatur dan di kekang; 4) Generasi digital selalu mengakses dengan geogle, yahoo atau situs lainnya, kemampuan belajar mereka jauh lebih cepat karena segala informasi ada diujung jari mereka (Sukiman, 2016). Teknologi digital mempunyai dampak positif dan negatif, kita sebagai orang dewasa harus membimbing, mengarahkan dan mengawasi anak lebih dominan serta mengambil manfaat positif dari teknologi. Penerapan pendidikan karakter pada era digital ini sangatlah penting agar generasi penerus bangsa mempunyai moral yang baik.Generasi penerus mencerminkan kualitas bangsa,apabila generasi penerusnya baik dalam kognitif dan moral maka baik pula suatu bangsa tersebut. Untuk itu keluarga,sekolah dan masyarakat mempunyai tanggungjawab untuk menciptakan generasi yang bermoral dan berakhlak baik.

\section{Simpulan}

Manajemen kepala madrasah Ibtidaiyah dalam menumbuhkan pendidikan karakter religius era digital dengan melakukan perencanaan,pengorganisasian,pelaksanaan dan evaluasi. Pendidikan karakter adalah segala sesuatu yang dilakukan kepala sekolah yang mampengaruhi karakter peserta didik. Guru membantu menumbuhkan watak peserta didik. Pendidikan karakter menanamkan kebiasaan tentang hal mana yang baik sehingga peserta didik menjadi paham tentang mana yang benar dan salah,mampu merasakan nilai yang baik dan mampu melaksanakannya,karena karakter seseorang itu tumbuh bila aktivitas dilakukan berulang-ulang secara rutin sehingga menjadi suatu kebiasaan yang akhirnya menjadi suatu karakter. Maka dari itu pendidikan karakter harus ditumbuhkan sejak kecil sehingga mereka mampu membawanya. Sampai usia dewasa Pendidikan karakter di madrasah dapat diterapkan pada semua mata pelajaran, setiap mata pelajaran yang berkaitan dengan norma-norma perlu dikembangkan serta dikaitkan dengan kehidupan sehari-hari. Pada era digital peran keluarga, guru, kepala sekolah dan masyarakat sekitar sangatlah penting dalam meningkatkan pendidikan karakter calon penerus bangsa, keluarga sebagai tempat utama dan pertama peserta didik kehidupan dan pendidikannya hendaklah diawasi dan dibimbing dengan penuh kasih sayang, tegas dan tepat. Kepala sekolah dan guru sebagai role model dalam pandangan anak-anak sehingga guru menjadi patokan bagi sikap anak didik dan masyarakat sekitar berperan dalam mengatasi dan memotivasi perkembangan karakter.

\section{Referensi}

Afrizal. (2015). Metode Penelitian Kualitatif Sebuah Upaya Mendukung Penggunaan Penelitian Kualitatif Dalam Berbagai Disiflin Ilmu. Rajawali Pers.

Amirulloh Syarbini. (2015). Buku Panduan Guru Hebat Indonesia. Ar-Ruzz Media.

Arifin M. Dan Barnawi. (2012). Manajemen Sarana dan Prasarana Sekolah. Ar-Ruzz Media. 
Aris Shoimin. (2014). Guru Berkarakter untuk Implementasi Pendidikan Karakter. Gava Media. Awaludin Pimay. (2013). Paradigma Humanis Strategi dan Dakwah. PT. RajaGrafindo Persada. Azam, U. (2016). Bimbingan dan konseling perkembangan di sekolah teori dan praktik. Deepublish. Daryannto, D. S. (2013). Implementasi Pendidikan Karakter di Sekolah. Gava Media.

Fathurrochman, I., Ristianti, D. H., \& bin Mohamed Arif, M. A. S. (2019). Revitalization of Islamic Boarding School Management to Foster the Spirit of Islamic Moderation in Indonesia. Jurnal Pendidikan Islam, 8(2), 239-259.

Febrianti, P. (2014). Pelayanan Kesejahteraan Sosial Terhadap Anak Terlantar di Panti Sosial Asuhan Anak (PSAA) Putra Utama 03 Tebet Jakarta Selatan.

Febrianti, Y. (2019). Upaya Pemuda Karang Taruna Gunung Tugel Community (Gtc) Dalam Membentuk Masyarakat Religius Melalui Kajian Keislaman Di Dusun Krajan Desa Baosan Lor Ponorogo.

Habsari, Z. (2017). Dongeng sebagai pembentuk karakter anak. Bibliotika: Jurnal Kajian Perpustakaan Dan Informasi, 1(1), 21-29.

Hartani A.L. (2011). Manajemen Pendidikan. Laks Bang Pressindo.

Jihad, Salimul, and M. S. (2018). Strategi Guru Dalam Mengatasi Kesulitan Belajar Siswa Dalam Pelajaran Mufrodat Kelas V1 Mi Nw Dasan Agung Mataram Tahun Pelajaran 2016/2017. ElTsaqafah: Jurnal Jurusan PBA, 17(1), 96-118.

Kurniawan, M. I. (2015). Tri Pusat Pendidikan Sebagai Sarana Pendidikan Karakter Anak Sekolah Dasar. PEDAGOGIA: Jurnal Pendidikan, 4(1), 41-49.

Kusen, K., Hidayat, R., Fathurrochman, I., \& Hamengkubuwono, H. (2019). Strategi Kepala Sekolah Dan Implementasinya Dalam Peningkatan Kompetensi Guru. Idaarah: Jurnal Manajemen Pendidikan, 3(2), 175-193.

Mia Zakaria dan Dewi Arumsari. (2018). Jeli Menbangun Karakter Anak. Bhuana Ilmu Populer.

Rahmadanni, dkk. (2017). Membangun Karakter Islami Anak dengan Mushafahah. CV. Budi Utama.

Ridwan Abdullah Sani dan M.Kadri. (2016). Pendidikan Karakter "Mengembagkan Karakter Anak yang Islami. Bumi Aksara.

Ristianti, D. H., Putrajaya, G., \& Fathurrochman, I. (2020). Organizational behavior management through group counseling discussions as a radicalism preventive effort. Jurnal Konseling dan Pendidikan, 8(1), 23-31.

Rohiat. (2010). Manajemen Sekolah: Teori dan Praktik. Rafika Aditama.

Sagala, S. (2011). Konsep dan Makna Pembelajaran. Alfabeta.

Salman Hasibuan. (2015). Buadaya Media dan Partisipasi Anak diarah digital, Proceding Of Internasional PostGraduate Comprence.

Sani, F. (2017). Metode Guru Pendidikan Agama Islam (Pai) Dalam Pembinaan Karakter Religius Siswa Melalui Kegiatan Keagamaan Di Smpn 1 Ngunut Tahun 2015/2016.

Saputra, A. E. (2019). Strategi Guru Dalam Membentuk Karakter Siswa Dan Siswi Smp Pgri 6 Bandar Lampung.

Sukiman, dkk. (2016). Seri Pendidikan Orang Tua:Mendidik Anak di Era Digital. Kementrian Pendidikan dan Kebudayaan.

Ula, S. S. (2013). Revolusi Belajar. Ar-Ruzz Media.

Yanto, M., \& Fathurrochman, I. (2019). Manajemen Kebijakan Kepala Madrasah Dalam Meningkatkan Mutu Pendidikan. Jurnal Konseling Dan Pendidikan, 7(3), 123-130. http://doi.org/10.29210/138700.h.2

Yanto., M. (2017). Strategi Guru Dalam Pendidikan Pembelajaran Bahasa Indonesia di SDN 45 Curup. Ejournal.iainbengkulu, 5(2). http:ejournal.iainbengkulu.ac.id indexs.php/manhaj/oi/verb $=$ listRecords \&metadata

Yanto.M. (2017). Penerapan Teori Sosial Dalam Menumbuhkan Akhlak Anak Kelas 1 MIN Rejang Lebong. Terampil,Jurnal:Pendidikan Pembelajaran Dasar, 4(2). https://doi.org/ 10.24092/Trampil,v4i2.2218

Yanto, M. (2020). Manajemen Kepala Sekolah Dalam Menumbuhkan Kompetensi Sosial Di Madrasah Ibtidaiyah Muhammadiyah 10 Karang Anyar Rejang Lebong. Jurnal Ar- Riayah, 4(1). http://journal.iaincurup.ac.id/index.php/jpd

Yanto, M. (2018). Manajemen dan Mutu Pembelajaran Bahasa Indonesia di SMPN 4 Rejang Lebong. Jurnal Ar-Riayah, 1(2), 192.

Yanto, M. (2019). Jurnal Manajemen Pendidikan Pada Tadris Bahasa Indonesia STAIN Curup. Jurnal Manajemen Pendidikan, 3(1), 77-84. http://jurnal.staincurup.ac.id/index php/jsmp/

Yanto, M. (2020). Manajemen Sekolah Dalam Pengelolaan Kegiatan Guru Bahasa Indonesia di Sekolah Dasar. Jurnal Estetik, 3(1), 15-26. doi:10.29240/estetik.V31i.1479 http://Journal. 
Iaincurup.ac.id/index. php/ estetik

Yulia Palupi. (2015). Digital Perenting Sebagai Wahan Terapi Untuk Menyeimbangkan Dunia Digital Dengan Dunia Nyata Dengan Anak.

Zubaedi. (2011). Desain Pendidikan Krakter: Konsep dan Aplikasinya dalam Lembaga Pendidikan. Kencana. 